IZA DP No. 6269

Less Myth, More Measurement:

Decomposing Excess Returns from the 1989 Minimum Wage Hike

Carl Lin

January 2012 


\title{
Less Myth, More Measurement: Decomposing Excess Returns from the 1989 Minimum Wage Hike
}

\author{
Carl Lin \\ Beijing Normal University \\ and IZA \\ Discussion Paper No. 6269 \\ January 2012 \\ IZA \\ P.O. Box 7240 \\ 53072 Bonn \\ Germany \\ Phone: +49-228-3894-0 \\ Fax: +49-228-3894-180 \\ E-mail: iza@iza.org
}

\begin{abstract}
Any opinions expressed here are those of the author(s) and not those of IZA. Research published in this series may include views on policy, but the institute itself takes no institutional policy positions.

The Institute for the Study of Labor (IZA) in Bonn is a local and virtual international research center and a place of communication between science, politics and business. IZA is an independent nonprofit organization supported by Deutsche Post Foundation. The center is associated with the University of Bonn and offers a stimulating research environment through its international network, workshops and conferences, data service, project support, research visits and doctoral program. IZA engages in (i) original and internationally competitive research in all fields of labor economics, (ii) development of policy concepts, and (iii) dissemination of research results and concepts to the interested public.
\end{abstract}

IZA Discussion Papers often represent preliminary work and are circulated to encourage discussion. Citation of such a paper should account for its provisional character. A revised version may be available directly from the author. 


\section{ABSTRACT}

\section{Less Myth, More Measurement: Decomposing Excess Returns from the 1989 Minimum Wage Hike}

In the book Myth and Measurement, Card and Krueger (1995) examine the economic impact of the 1989 minimum wage hike on the welfare of 110 firms which employ a disproportionate number of minimum-wage workers. Their results show mixed evidence that excess returns associated with news about the 1989 minimum-wage legislation. This paper re-examines this question by decomposing excess returns. Our simple and intuitive approach attributes excess returns to either differences in market performances (economy-wide factors) or firmspecific traits (individualistic factors). We likewise show that, generally, minimum wage legislation had little or no effect on employer wealth. However, by decomposing total excess returns, we find that the apparent lack of an effect is a consequence of two off-setting forces: (1) a negative effect arising from firm-specific traits (adverse information on minimum-wage worker employers) and (2) a positive effect arising from market performance. In other words, we show that while the aggregate effect of the 1989 minimum wage hike was neutral, there was a significant negative impact on firms that was neutralized by positive market performance.

JEL Classification: G14, J31, J38

Keywords: minimum wage, excess returns, decomposition

Corresponding author:

Carl Lin

School of Economics and Business Administration

Beijing Normal University

No.19 Xin Jie Kou Outer St.

Haidian Dist.

Beijing 100875

China

E-mail: csmlin@bnu.edu.cn

\footnotetext{
* I would like to thank Ira Gang, John Knight, Myeong-Su Yun and participants in the IZA Research Seminar and Wuhan University Workshop for helpful comments and discussions.
} 


\section{Introduction}

In comparison with the vast literature on the effects of the minimum wage on employment and wages, research of the influence of minimum wages on firm profits has been rather sparse. Given that most of the theoretical models of the minimum wage start from the assumption that firms operate in a way that maximizes profits (or minimizes costs), the models predict an increase in the minimum wage will reduce firm profits. However, there are only a few empirical studies that examine the effects of the minimum wage on profits.

One recent study that addresses this question is Draca, Machin, and Van Reenan (2011). They directly estimate the link between profits and the re-introduction of the minimum wage in the United Kingdom using firm-level data on profit margins. Their study shows that the introduction of the minimum wage had a negative effect on the profitability of low-wage employers in the United Kingdom. Neumark and Wascher (2008) state results that seem reasonably well supported by the data and consistent with most theoretical models of the low-wage labor market.

In the book Myth and Measurement, Card and Krueger (1995) examine the economic impact of 1989 minimum wage hike on the welfare of 110 firms which employ a disproportionate number of minimum wage workers. They combine data on stock returns with news about the minimum wage legislation to conduct an event study of the effects of changing expectations about future minimum wage increases on firm profits. Their results show mixed evidence that excess returns associated with news about the 1989 minimum wage legislation are generally unsystematic and rarely seem to affect employer wealth. In this paper, we re-examine this question by introducing an approach to decomposing excess returns. This simple and intuitive approach attributes excess returns to either differences in market performances (economy-wide factors) or firmspecific traits (individualistic factors).

Our results confirm Card and Krueger (1995), showing that, generally, the minimum wage legislation had little or no effect on employer wealth. However, by decomposing total excess returns, we find that the apparent lack of an effect is a consequence of two off-setting forces: (1) a negative effect arising from firm-specific traits (adverse information on minimum-wage worker employers) and (2) a positive effect 
arising from market performance. In other words, we show that while the aggregate effect of the 1989 minimum wage hike was neutral, there was a significant negative impact on firms that was neutralized by positive market performance.

In section 2, we introduce the approach. Section 3 is the application in which we re-examine the results of the 1989 minimum wage hike in Card and Krueger (1995). Section 4 is the conclusion.

\section{Decomposing Excess Returns}

\subsection{Sources of Return}

In the discussion of the sources of return, we often identify sources of return that originated from the issuer of the security (the firm) and sources of return that affected securities in general. The firm-specific return is usually called unsystematic return, because it is unique to each issuer of securities and does not affect all financial securities. The market-related return affecting all securities is called the systematic return. In other words, the security return can be divided into two components: a systematic component that is correlated with the overall market performance and an unsystematic component that is independent of the market. That is,

\section{Security return $=$ Systematic return + Unsystematic return}

In order to analyze or measure the degree of systematic and unsystematic return that a security contains, a model of the return-generating process must be identified. A widely accepted model to achieve this is called the "market model". The classic market model is shown by equation(1):

$$
\begin{gathered}
R_{i t}=\alpha_{i}+\beta_{i} R_{m t}+\varepsilon_{i t} \\
E\left[\varepsilon_{i t}\right]=0 \quad \operatorname{Var}\left[\varepsilon_{i t}\right]=\sigma_{\varepsilon_{i}}^{2},
\end{gathered}
$$

where:

$R_{i t}=$ the return on the $i$ th security during time $t$;

$\alpha_{i}=$ the intercept of the regression model;

$\beta_{i}=$ the slope of the regression model which is a measure of systematic risk of the $i$ th security;

$R_{m t}=$ the random return on the market index during time $t$;

$\varepsilon_{i t}=$ the disturbance term of security $i$ during time $t$. 
In general, equation (1) identifies a linear relationship between the return on the market $\left(R_{m t}\right)$ and the return on an individual security $\left(R_{i t}\right)$ during time $t$.

In addition to the return on security, investors are also interested in its risk or variability. Chen and Keown (1981) show that the variance of a security's return is the sum of the degree of systematic risk and the degree of unsystematic risk which is contained in the total risk of the security. ${ }^{2}$ Therefore, by decomposing the variance of the security's return, one can know how much of the risk of an individual security return is due to the market (systematic risk) and how much is due to the firm (unsystematic risk).

Besides the risk of a security's return, excess returns to a security is of high interest for researchers and investors. However, unlike risk of a security's return, it is unclear how much of the excess returns can be attributed to market performance or firmspecific traits. In the next section, we introduce a simple and intuitive approach to address this question by attributing excess returns to either differences in market performances (economy-wide factors) or firm-specific traits (individualistic factors).

\subsection{Decomposing Excess Returns}

An often used methodology to study labor market outcomes by groups (gender, race, etc.) is to decompose mean differences in log wages based on regression models in a counterfactual manner. Decomposition techniques for linear regression models have been used for many decades. This heterogeneous collection of techniques is more generally referred to as regression standardization (Althauser and Wigler 1972, Duncan 1969, Duncan, Featherman and Duncan 1968, Coleman and Blum 1971, Coleman, Berry, and Blum 1971, Winsborough and Dickinson 1971). Oaxaca (1973) and Blinder (1973) introduced regression decomposition to the economics literature.

As stated in Powers, Yoshida and Yun (2011), decomposition is widely used in social research to quantify the contributions to group differences in average predictions from regression models. The technique utilizes the output from regression models to parcel out components of a group difference in a statistic (such as a mean or proportion) which can be attributed to differences between groups (i.e., differences in characteristics, endowments, or attributes) and to differences in the effects of characteristics (i.e.,

\footnotetext{
${ }^{2}$ The process is called variance decomposition. The variance of the return for an individual security is often used to measure the risk of the individual security.
} 
differences in the returns, coefficients, or behavioral responses). Next, we introduce a method allowing decomposition of a firm's excess return into differences in economywide and individualistic factors.

Suppose for firm $i$ on any day, the market model in equation (1) can be written as,

$$
\begin{gathered}
R_{i}=a_{i}+\beta_{i} R_{m} \\
a_{i}=\alpha_{i}+\varepsilon_{i},
\end{gathered}
$$

where $\beta$ is the measure of systematic return (due to market performance) and $a$ is the measure of unsystematic return (due to firm-specific traits).

To illustrate, Figure 1 shows the time line of estimation and prediction periods which are used to decompose excess returns of a firm.

\section{Figure 1 Time Line of Decomposing Excess Returns}

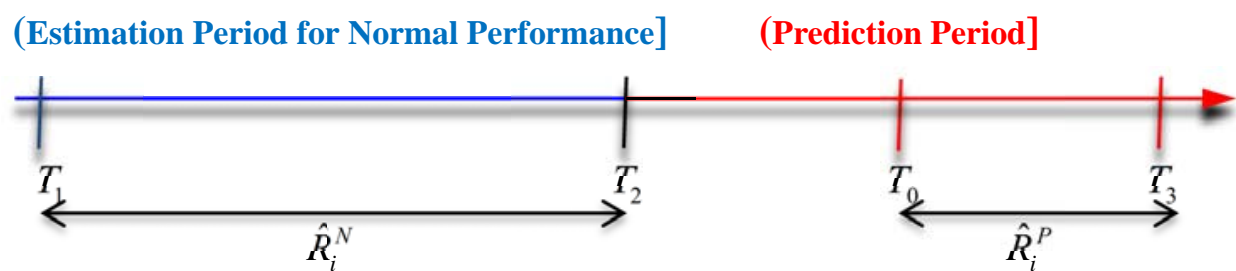

$\hat{R}_{i}^{N}$ represents the normal performance of a firm's stock return from $T_{1}$ to $T_{2}$. Typically, 255 days is selected to correspond approximately to the number of trading days in a calendar year. $T_{0}$ is the event day and $\hat{R}_{i}^{P}$ is the predicted return of the firm.

At the firm level, excess return ( $A R$, or prediction error) of firm $i$ on any day during the prediction period can be calculated by,

$$
\begin{aligned}
A R_{i} & =\hat{R}_{i}^{P}-\hat{R}_{i}^{N} \\
& =\hat{R}_{i}^{P}-\left(\hat{\alpha}_{i}^{N}+\hat{\beta}_{i}^{N} R_{m}^{N}\right) \\
& =\hat{\alpha}_{i}^{P}-\hat{\alpha}_{i}^{N}+\hat{\beta}_{i}^{P}\left(R_{m}^{P}-R_{m}^{N}\right)+R_{m}^{N}\left(\hat{\beta}_{i}^{P}-\hat{\beta}_{i}^{N}\right)
\end{aligned}
$$

where:

$\hat{R}_{i}^{P}=$ the predicted return of firm $i$;

$\hat{R}_{i}^{N}=$ the estimated normal performance return of firm $i$;

$\hat{\alpha}_{i}^{N}=$ the estimated intercept from the estimation period of firm $i$;

$\hat{\alpha}_{i}^{P}=$ the estimated intercept from the post-event day period of firm $i$; 
$\hat{\beta}_{i}^{N}=$ the estimated slope from the estimation period of firm $i$;

$\hat{\beta}_{i}^{P}=$ the estimated slope from the post-event day period of firm $i$;

$R_{m}^{N}=$ the mean market performance return from the estimation period;

$R_{m}^{P}=$ the mean market performance return from the post-event day period.

At industry level, the mean excess return of an industry containing $N$ firms is,

$$
\overline{A R_{i}}=\frac{1}{N} \sum_{i=1}^{N}\left(\hat{\alpha}_{i}^{P}-\hat{\alpha}_{i}^{N}\right)+\frac{1}{N} \sum_{i=1}^{N} \hat{\beta}_{i}^{P}\left(R_{m}^{P}-R_{m}^{N}\right)+\frac{1}{N} \sum_{i=1}^{N} R_{m}^{N}\left(\hat{\beta}_{i}^{P}-\hat{\beta}_{i}^{N}\right)
$$

After the estimation period, we can get the ex post estimated systematic risk $\hat{\beta}^{P}$ and ex post individualistic component $\hat{\alpha}^{P}$. $R_{m}^{P}$ is the ex post mean market return. Therefore, equation (4) can be expressed as,

$$
\overline{A R_{i}}=\underbrace{\frac{1}{N} \sum_{i=1}^{N}\left(\hat{\alpha}_{i}^{P}-\hat{\alpha}_{i}^{N}\right)+\underbrace{\frac{1}{N} \sum_{i=1}^{N} R_{m}^{N}\left(\hat{\beta}_{i}^{P}-\hat{\beta}_{i}^{N}\right)}_{\text {Dot to differences in systematic risks }}}_{\text {Due to differences in firm-specific traits }}+\underbrace{\underbrace{\frac{1}{N} \sum_{i=1}^{N} \hat{\beta}_{i}^{P}\left(R_{m}^{P}-R_{m}^{N}\right)}_{\text {Due to differences in market performances }}}_{\text {Dxplained by the market }}
$$

The mean excess returns $\overline{A R_{i}}$ of industry $i$ can then be decomposed into three terms. The first and second terms represent the parts that are not explained by the market. More precisely, the first term represents how much of the excess returns can be attributed to differences in firm-specific traits. The second term represents the mean excess returns which can be attributed to differences in systematic risks, $\beta$. The third term represents the part that is explained by the market which is equivalent to differences in market performances.

To illustrate the approach, in the next section we first replicate the results of Chapter 10 in the book Myth and Measurement by Card and Krueger (1995). Then we employ the approach to re-examine the effect of 1989 minimum wage hike. 


\section{Revisiting Myth and Measurement}

\subsection{A Brief Look at Events Leading to the 1989 Minimum-Wage Legislation ${ }^{3}$}

To examine the stock market's reaction to news about the minimum wage, it is important to identify events that change investor's expectations about the future course of the minimum wage. Card and Krueger (1995) use past issues of the Wall Street Journal and other sources in order to identify key events connected to 1989 legislation on the minimum wage.

Periodically since 1938, the U.S. Congress has amended the Fair Labor Standards Act (FLSA) to increase the level of the minimum wage. In the years between increases, the real value of the minimum wage has been eroded by inflation, causing a sawtooth pattern in the real value of the minimum over time. In 1977, the U.S. Congress amended the FLSA to raise the minimum wage to $\$ 2.65$ per hour in 1978 , to $\$ 2.90$ per hour in 1979, to \$3.10 per hour in 1980, and to \$3.35 per hour in 1981.

Under President Reagan, the historical pattern of periodic increases in the minimum wage was halted. In all likelihood, investors came to regard the prospects of a minimum wage increase in the Reagan era as remote and lowered their forecasts of the long-run level of the minimum wage.

In March 1987, Senator Edward Kennedy and Representative Augustus Hawkins introduced legislation to increase the minimum wage to $\$ 4.65$ per hour by 1990 . In June 1987, President Reagan signaled that he might soften his opposition to a minimum wage increase if the legislation were weakened to include a subminimum wage for youths. Hearings lasting several months were held on the proposed increase. On September 19, 1988, then-Vice President Bush announced during the presidential campaign that he would support an increase in the minimum wage. Later that month, however, a Republican-led filibuster in the Senate thwarted the Kennedy and Hawkins effort to increase the minimum wage. The vote fell five votes short of reaching cloture.

In early March of 1989, Congress and President Bush again considered the issue. The Bush administration signaled that it would propose increasing the hourly minimum to $\$ 4.25$ by 1992 , provided that employers were allowed to pay a short-term "training

\footnotetext{
${ }^{3}$ This section is adapted from Card and Krueger (1995) pp. 328-29.
} 
wage” of $\$ 3.35$ to youths. Shortly thereafter, the Senate Labor Panel voted 11 to 6 in favor of raising the minimum to $\$ 4.65$ per hour. The administration signaled its resolve to veto any legislation that would "go beyond its proposal of raising the minimum to $\$ 4.25$ per hour, with a training wage of \$3.35”. On March 23, 1989, the House voted by a 248 to 171 margin on H.R. 2 to raise the minimum to $\$ 4.55$ per hour by 1991 . The White House reiterated its resolve to veto his legislation. Nonetheless, the Senate followed the lead of the House and, on April 12, 1989, voted 62 to 37 in favor of the Senate minimum wage increase bill S-4. In mid-May 1989, after a conference, both house of Congress approved a bill to raise the minimum wage to $\$ 4.55$ per hour. The number of votes in favor of this legislation in both the Senate and the House, however, fell short of the margin required to override a presidential veto. President Bush vetoed the legislation on June 13, 1989. Although a veto had been threatened, the actual veto was significant because it was the first of Bush's presidency. The following day, the House again voted on H.R. 2, and, as expected, the vote fell short of the required number to override a veto.

The U.S. Congress took up the minimum wage again in the fall of 1989. The House Labor Panel voted to increase the minimum to $\$ 4.25$ per hour over two years, and to set a 60-day subminimum wage. Labor Secretary Elizabeth Dole reiterated the President's intention to veto any bill that increased the minimum wage to more than $\$ 4.25$ per hour in less than three years. On November 1, 1989, the Wall Street Journal reported that President Bush and Congressional Democrats had reached a compromise agreement on the minimum wage, clearing the way for eventual passage of the legislation. On November 1, 1989, the House passed H.R. 2710 by a margin of 382 to 37. This bill increased the minimum wage to $\$ 3.80$ per hour on April 1,1990 , and to $\$ 4.25$ per hour on April 1, 1991, and created a 60-day youth subminimum wage. One week later, the Senate passed identical legislation by a vote of 89 to 8 .

\subsection{Implementation}

From Card and Krueger (1995) Table A.10.1, we collect daily stock return data on the same sample of 110 publicly-traded firms that are particularly likely to have been affected by the 1989 minimum wage increase. The sample consists of 110 firms in the restaurant, department store, grocery store, merchandise store, variety store, hotel and motel, linen supply, and motion picture theater industries. Companies in these industries 
tend to employ a disproportionate number of minimum wage workers. A complete list of the firms is included in Appendix Table A 1.

Daily stock returns for the 110 companies and market returns are obtained from the Center for Research in Security Prices (CRSP). Then we run a daily stock return model using equation (1). Formally, we estimate the "normal performance" of firm $i$ in the one year prior to the minimum-wage legislation using equation (6):

$$
R_{i t}=\alpha_{i}+\beta_{i} R_{m t}+\varepsilon_{i t}
$$

where $R_{i t}$ is the return on the common stock of firm $i$ on day $t$, adjusted for stock splits and dividends; $R_{m t}$ is the return on the equally-weighted NYSE/AMEX portfolio on day t. $\alpha_{i}$ and $\beta_{i}$ are regression coefficients; and $\varepsilon_{i t}$ is the error term for firm $i$ on day $t$.

To be consistent with Card and Krueger (1995), equation (6) is estimated using data on returns in 1987 to get the normal performance of each company. Next, the mean predicted return of each company after an event from day 1 to day 10 is obtained by estimating equation (6). Mean excess returns ( $A R$ ) are then calculated and decomposed for each company on each day. Lastly, using equation (5) the result attributes the excess returns immediately to differences in firm-specific traits, systematic risks and market performances. Formally, the implementation steps are summarized as,

1. Run a daily stock return market model to get the normal performance for each firm.

2. Estimate the post-event performance to get the predicted return for each firm.

3. Decompose excess returns using equation (3) 4 .

4. Analyze the results.

\subsection{Less Myth, More Measurement}

Card and Krueger (1995) quantify the impact of minimum-wage legislation on firm profits. Their results show mixed evidence that news about a minimum wage hike induces investors to adjust their valuation of firms downward. Excess returns associated with news about the 1989 minimum-wage legislation are generally unsystematic. They conclude that in the sample of events they have examined, news about a minimum wage

\footnotetext{
${ }^{4}$ Excess return decomposition results can be obtained using mvdcmp, the Stata program, by Power, Yoshioka and Yun (2010). The program is available at http://www.tulane.edu/ msyun/research.htm
} 
hike rarely seems to have effect on shareholder wealth.

In this section, we re-examine their results using the method developed in the previous sections. Card and Krueger (1995) describes 20 newsworthy events leading up to the 1989 amendments to the Fair Labor Standards Act. The descriptions are generally based on the title of the Wall Street Journal's article on the event. The date corresponds to the publication date of the article; the event usually occurred on the preceding day. There are six minimum-wage legislation events which Card and Krueger (1995) show are interesting and worth examining. ${ }^{5}$ Their results show that almost all the mean excess returns are small and not statistically significant from zero. On the day that the event was described in the Wall Street Journal, only two of the twenty mean excess returns are statistically significant different from zero at the $10 \%$ level.

To be comparable, we replicate their results and show that the graphs (Figure 2 to Figure 7) are identical to those in Card and Krueger (1995). These six legislation events are:

1. June 12, 1987: Reagan may ease minimum wage stand.

2. March 4, 1988: Panel votes to sharply boost minimum wage.

3. September 27, 1988: Democrats' bid to boost minimum wage thwarted by GOP filibuster.

4. March 3, 1989: Bush to propose raising minimum wage $\$ 4.25$ to lower training wage.

5. June 14, 1989: Bill on raising minimum wage vetoed by Bush.

6. November 1, 1989: Compromise bill on minimum wage reached and the House passed H.R. 2710 by a margin of 382 to 37.

\subsubsection{June 12, 1987 - Headline: Reagan “May” Ease Minimum Wage Stand}

On June 12, 1987, Wall Street Journal reported that Reagan signaled he might soften his opposition to a minimum wage increase. Figure 2 depicts the 10 days mean excess return and cumulative mean excess return around June 12. Table 1 reports the two-fold and three-fold decomposition result of excess returns from day 1 to day 10 .

It seems this news may have a negative effect on the profits of the sample

\footnotetext{
${ }^{5}$ Card and Krueger (1995) pp.334-337.
} 
companies, but the signal that Reagan "may" ease minimum wage stand doesn’t sound strong and decisive which the direction of the impact is likely to be ambiguous. In fact, from Table 1 although the post-event mean excess return is .247\% and significant at $1 \%$ level, we find that $35 \%$ of the mean excess returns is explained by the market performance and is significant at $10 \%$ level, though $65 \%$ of the mean excess returns is not explained by the market and is not statistically significant. Furthermore, we found that almost all (64.917\%) the excess returns can be attributed to difference in firmspecific traits $(\alpha)$ and very little $(.003 \%)$ can be attributed to difference in systematic risks ( $\beta$ ). However, both are not statistically significant from zero. Hence, the insignificant decomposition results support the prediction of Card and Krueger (1995).

Figure 2 June 12, 1987: Reagan “May” Ease Minimum Wage Stand

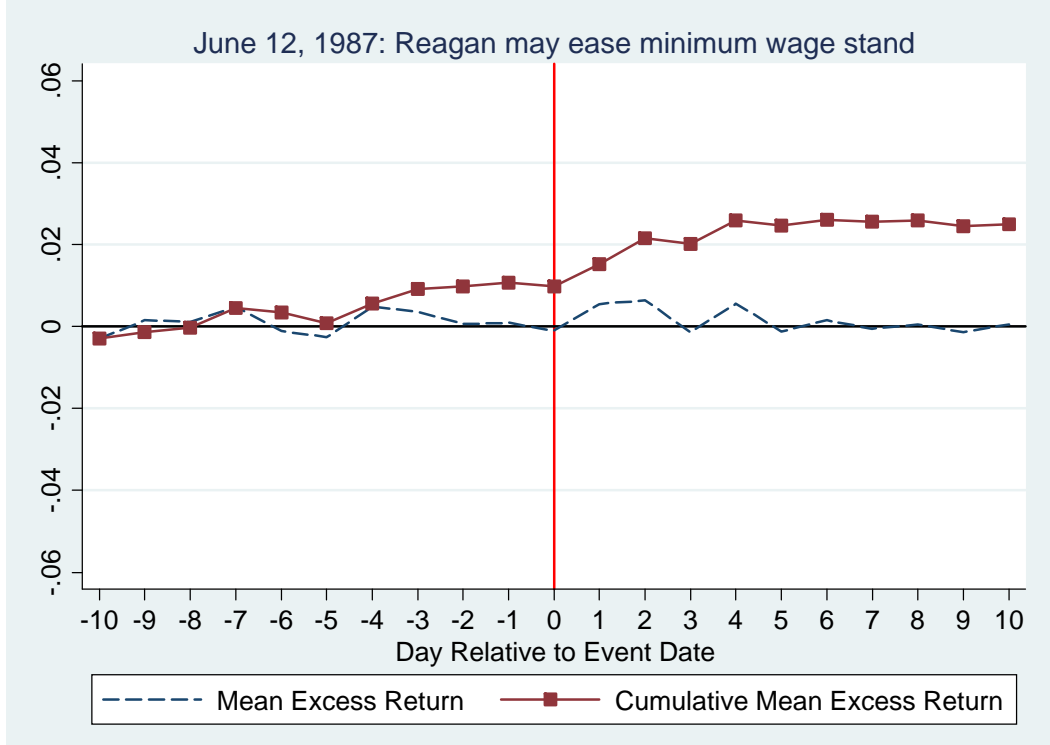

Table 1 June 12, 1987: Reagan “May” Ease Minimum Wage Stand

\begin{tabular}{lcc}
\hline \hline Prediction: Ambiguous or Negative Effect & Day 1-10 (\%) & Share \\
\hline Mean Excess Return & $\begin{array}{l}.24738^{* * *} \\
(.085362)\end{array}$ & $100 \%$ \\
Explained by the Market & $\begin{array}{l}.086779^{*} \\
(.052248)\end{array}$ & $35.08 \%$ \\
Not Explained by the Market & $\begin{array}{l}.1606 \\
(.10008)\end{array}$ & $64.92 \%$ \\
\hline Mean Excess Return & $\begin{array}{l}.24738^{* * *} \\
(.085362)\end{array}$ & $100 \%$ \\
Due to Differences in Market Performances & $.086779 *$ & $35.08 \%$ \\
\hline
\end{tabular}


$(.052248)$

Due to Differences in Systematic Risks $\beta$

7.3119e-06

(1.3225e-04)

$.003 \%$

.1606

Due to Differences in Firm-specific Traits $\alpha$

\subsubsection{March 4, 1988 - Headline: Panel Votes to Sharply Boost Minimum Wage}

On March 4, 1988, Senate Panel votes to sharply boost minimum wage. When the news was released, the interpretation should be adverse to employers' profit. Card and Krueger (1995) predict a negative effect on the wealth of sample companies. They show that the cumulative excess return is decreasing after March 4 as shown in Figure 3, but neither cumulative excess return nor mean excess return is statistically significant from zero.

Table 2, however, offers a different perspective than Card and Krueger (1995). By decomposing excess return, we find that even though the post-event mean excess return is only $0.077 \%$ and not significant, the strong pull and push between market and nonmarket forces play a very active role. The market performs exceptionally well from day 1 to day 10 (compared to its 1987 performance) which should drive the profits of the 110 sample companies up by a large magnitude. Nevertheless, the news of March 4 generates another strong but negative effect on the sample companies which offsets most of the increase. The three-fold result in the lower panel of Table 2 supports the findings because the difference in systematic risk $\beta$ only plays a very little role compared to the firmspecific traits, $\alpha$.

Card and Krueger (1995) show the news on March 4, 1988 has an insignificant but negative effect on minimum wage firms' wealth. We show that although the effect is not significant, the news that Senate Panel voted to sharply boost the minimum wage indeed had a strong and significantly negative impact on the firms' wealth. But as the market was performing exceptionally well, the negative impact is neutralized. 
Figure 3 March 4, 1988: Panel votes to sharply boost minimum wage

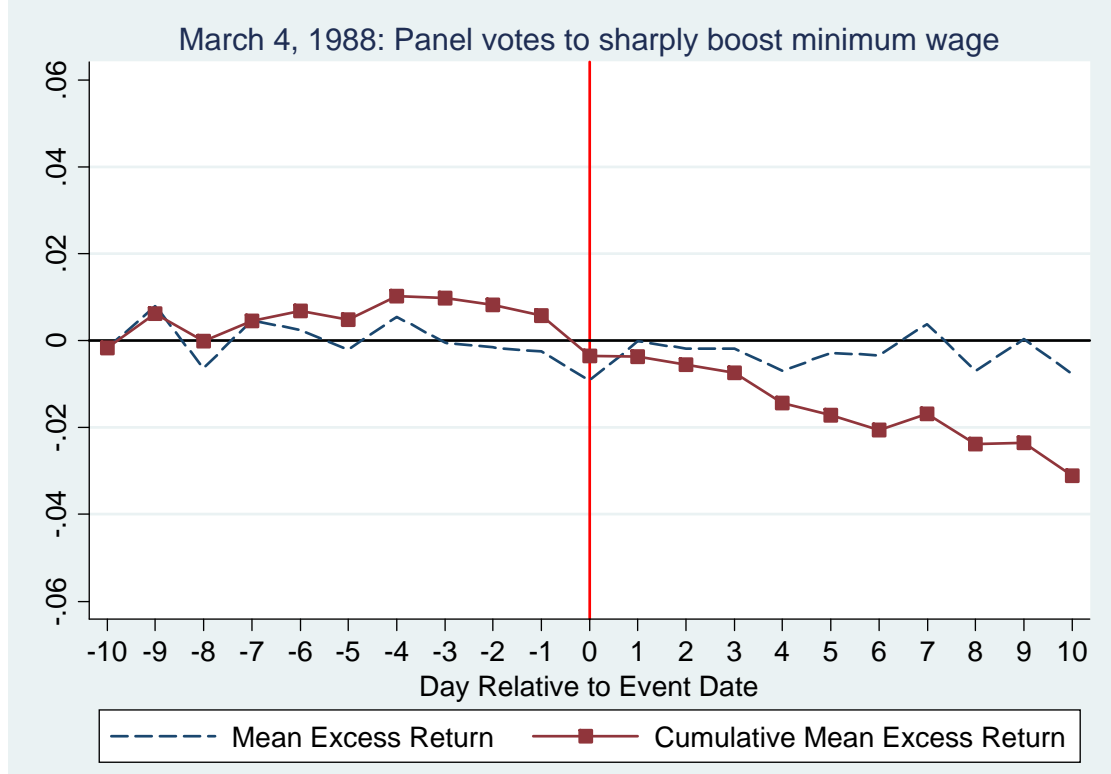

Table 2 March 4, 1988: Panel votes to sharply boost minimum wage

\begin{tabular}{lcc}
\hline \hline \multicolumn{1}{c}{ Prediction: Negative Effect } & Day 1-10 (\%) & Share \\
\hline Mean Excess Return & $\begin{array}{c}.077749 \\
(.093774)\end{array}$ & $100 \%$ \\
Explained by the Market & $\begin{array}{c}.44996^{* * *} \\
(.092915)\end{array}$ & $578.72 \%$ \\
Not Explained by the Market & $\begin{array}{c}-.37221^{* * *} \\
(.13201)\end{array}$ & $-478.72 \%$ \\
\hline Mean Excess Return & $\begin{array}{c}.077749 \\
(.093774)\end{array}$ & $100 \%$ \\
Due to Differences in Market Performances & $\begin{array}{l}.44996^{* * *} \\
(.092915)\end{array}$ & $578.72 \%$ \\
Due to Differences in Systematic Risks $\beta$ & $\begin{array}{c}9.2706 \mathrm{e}-04 \\
(9.2680 \mathrm{e}-04)\end{array}$ & $1.20 \%$ \\
Due to Differences in Firm-specific Traits $\alpha$ & $\begin{array}{c}-.37313^{* * *} \\
(.13266)\end{array}$ & $-479.92 \%$ \\
\hline \hline
\end{tabular}

\subsubsection{September 27, 1988 - Headline: Democrats' Bid to Boost Minimum Wage Thwarted by GOP Filibuster}

On September 19, 1988, Bush announced during the presidential campaign that he "could" support an increase in the minimum wage. After six days, a Republican-led filibuster in the Senate thwarted the Kennedy and Hawkins effort to increase the 
minimum wage. The vote fell five votes short of reaching cloture. According to Card and Krueger (1995), the event contains the strongest evidence that investors view a minimum-wage hike as having negative consequences for corporate profits. Figure 4 shows the cumulative excess returns around the time of the final cloture vote on the Republican-led filibuster of the Kennedy-Hawkins minimum-wage bill. The cumulative excess return in the 10-day interval around the successful filibuster was nearly $4 \%$. Moreover, negative excess returns are apparent a few trading days before the final cloture vote, which coincides with the date of an earlier vote on cloture.

Table 3 reports the mean excess returns in the 10-day interval is $0.42 \%$ and significant. In the 10 days, $81.6 \%$ of the mean excess return cannot be explained by the market which means the event has a significant and large effect on the sample companies; on the other hand, only $18.4 \%$ can be explained by the market. This point can be supported by looking at the three-fold decomposition. The difference in systematic risks is small and not significant.

Our results here further support the argument of Card and Krueger (1995) and show that firm-specific characteristics account for more than $80 \%$ of the good news to the firms to the event on September 27, 1988. Market performance only contributes $18 \%$.

Figure 4 September 27, 1988: Democrats' bid to boost minimum wage thwarted by GOP filibuster

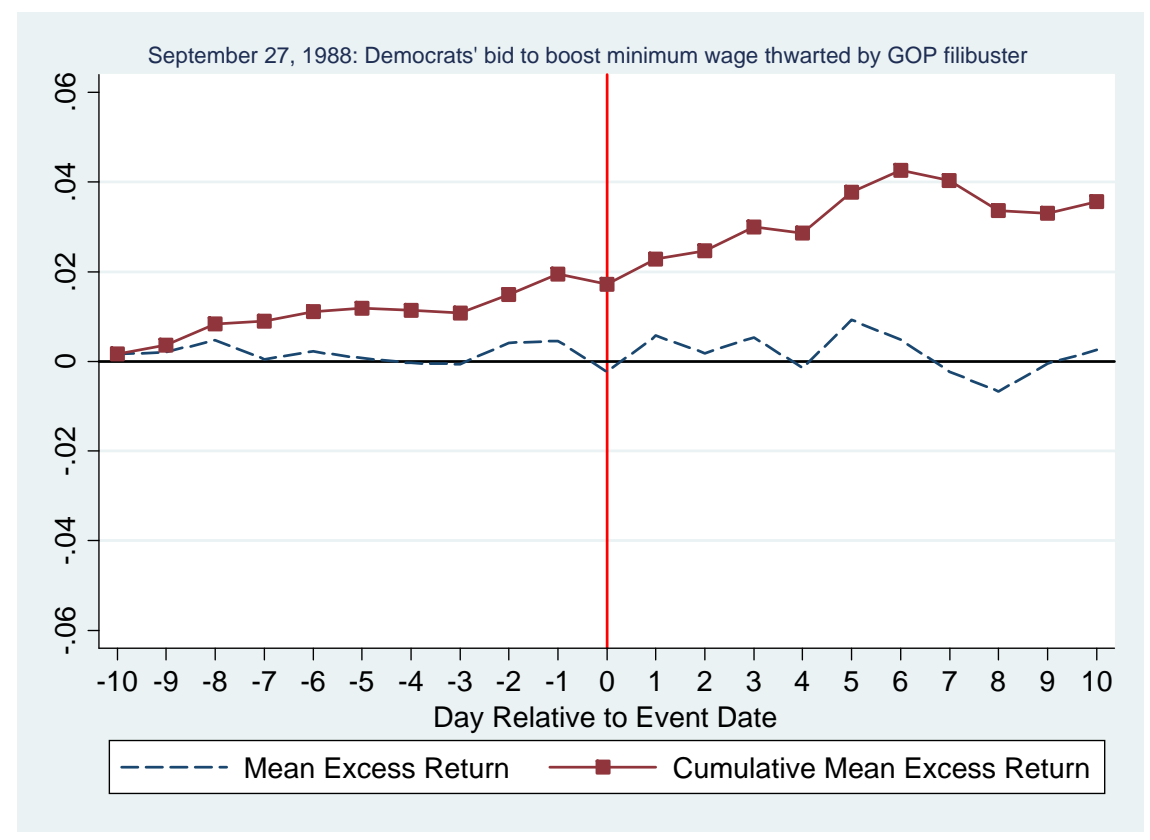


Table 3 September 27, 1988: Democrats' bid to boost minimum wage thwarted by GOP filibuster

\begin{tabular}{lcc}
\hline \hline \multicolumn{1}{c}{ Prediction: Positive Effect } & Day 1-10 (\%) & Share \\
\hline Mean Excess Return & $\begin{array}{c}.42005^{* * *} \\
(.094595)\end{array}$ & $100 \%$ \\
Explained by the Market & $\begin{array}{c}.077214^{* * *} \\
(.025621)\end{array}$ & $18.38 \%$ \\
Not Explained by the Market & $\begin{array}{l}.34283^{* * *} \\
(.098003)\end{array}$ & $81.62 \%$ \\
\hline Mean Excess Return & $\begin{array}{l}.42005^{* * *} \\
(.094595)\end{array}$ & $100 \%$ \\
Due to Differences in Market Performances & $\begin{array}{l}.077214^{* * *} \\
(.025621)\end{array}$ & $18.38 \%$ \\
Due to Differences in Systematic Risks $\beta$ & $\begin{array}{c}-4.2676 \mathrm{e}-04 \\
(.0010391)\end{array}$ & $-.10 \%$ \\
Due to Differences in Firm-specific Traits $\alpha$ & $\begin{array}{l}.34326^{* * *} \\
(.098279)\end{array}$ & $81.72 \%$ \\
\hline \hline
\end{tabular}

\subsubsection{March 3, 1989 - Headline: Bush to Propose Raising Minimum Wage $\$ 4.25$ to Lower Training Wage}

After failing to increase the minimum wage in the Senate in September of 1988, in early March of 1989, Congress and President Bush again considered the issue. On March 3, 1989, the Bush administration signaled that it would propose increasing the hourly minimum to $\$ 4.25$ by 1992 , provided that employers were allowed to pay a short-term “training wage” of \$3.35 to youths. The prediction of the effect on employers' wealth can be negative or ambiguous when the news was released as merely a proposal. Investors should be more responsive to news which is decisive to the increase of minimum-wage legislation.

Graphically in Figure 5 we see little change before and after March 3. The postevent 10 -day mean excess return is $0.126 \%$ which is also not significant from zero. However, decomposition results show that approximately $85 \%$ of mean excess return can be attributed to differences in market performances and is statistically significant at $1 \%$ level. Differences in systematic risk is significant at the $10 \%$ level but only contribute $0.78 \%$ of the mean excess return. Although differences in firm specific-traits contribute $14 \%$, it is not statistically significant. 
Figure 5 March 3, 1989: Bush to propose raising minimum wage $\$ 4.25$ to lower training wage

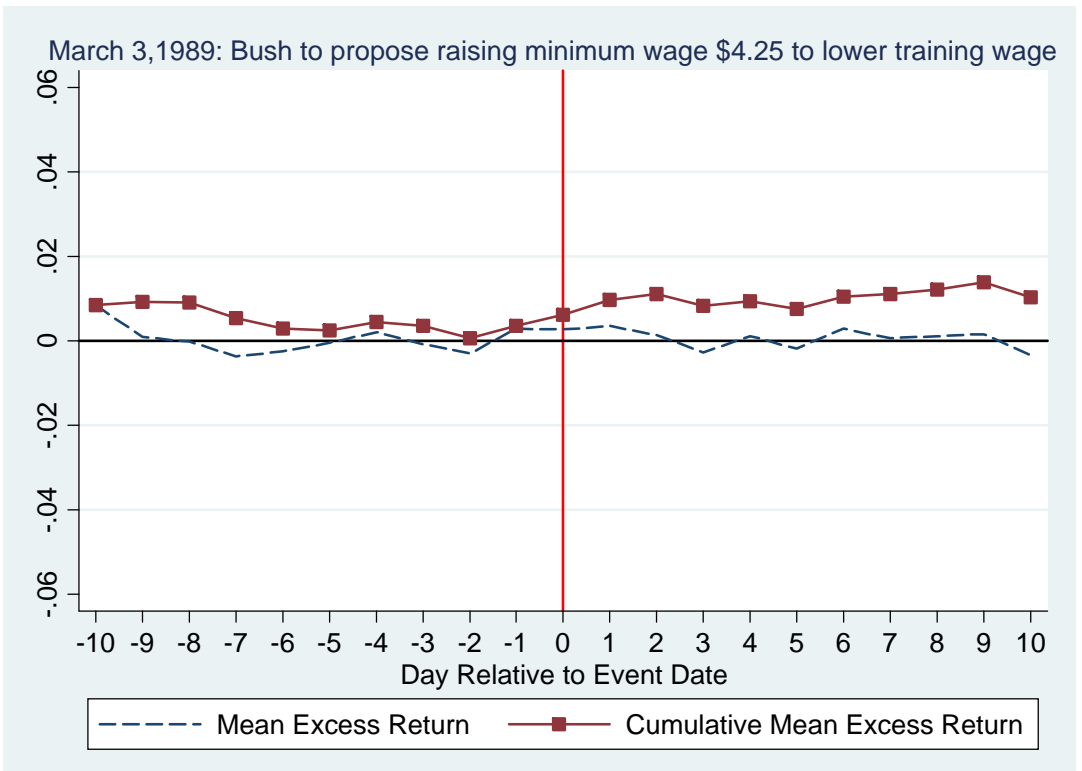

Table 4 March 3, 1989: Bush to propose raising minimum wage $\$ 4.25$ to lower training wage

\begin{tabular}{lcc}
\hline \hline Prediction: Ambiguous or Negative Effect & Day 1-10 (\%) & Share \\
\hline Mean Excess Return & $\begin{array}{c}.12594 \\
(.076941)\end{array}$ & $100 \%$ \\
\multicolumn{1}{c}{ Explained by the Market } & $\begin{array}{c}.10732 * * * \\
(.013991)\end{array}$ & $85.22 \%$ \\
Not Explained by the Market & $\begin{array}{c}.01862 \\
(.078203)\end{array}$ & $14.78 \%$ \\
\hline Mean Excess Return & $\begin{array}{c}.12594 \\
(.076941)\end{array}$ & $100 \%$ \\
Due to Differences in Market Performances & $\begin{array}{l}.10732 * * * \\
(.013991)\end{array}$ & $85.22 \%$ \\
Due to Differences in Systematic Risks $\beta$ & $\begin{array}{l}9.8981 \mathrm{e}-04 * \\
(5.9451 \mathrm{e}-04)\end{array}$ & $0.78 \%$ \\
Due to Differences in Firm-specific Traits $\alpha$ & $\begin{array}{c}.01763 \\
(.078311)\end{array}$ & $14.00 \%$ \\
\hline \hline
\end{tabular}

\subsubsection{June 14, 1989 - Headline: Bill on Raising Minimum Wage Vetoed by Bush}

On June 13, 1989, President Bush vetoed the minimum-wage legislation. Although a veto had been threatened, the actual veto was significant because it was the first of Bush's Presidency. The following day, the House again voted on H.R. 2, and, as expected, the 
vote fell short of the required number to override a veto. Card and Krueger (1995) show that the event has no effect on sample companies, as is apparent from Figure 6. The postevent mean excess return $0.009 \%$ is small. Although their prediction is correct, it is not statistically significant.

Though their results show no effect, by decomposing excess return we found that $85 \%$ of it can be significantly attributed to differences in market performances. The differences in systematic risks $\beta$ is $-4 \%$, which is not significant from zero. However, the differences in firm-specific traits contributes $18.5 \%$ of the excess return which is consistent to the prediction albeit statistically insignificant.

Figure 6 June 14, 1989: Bill on raising minimum wage vetoed by Bush

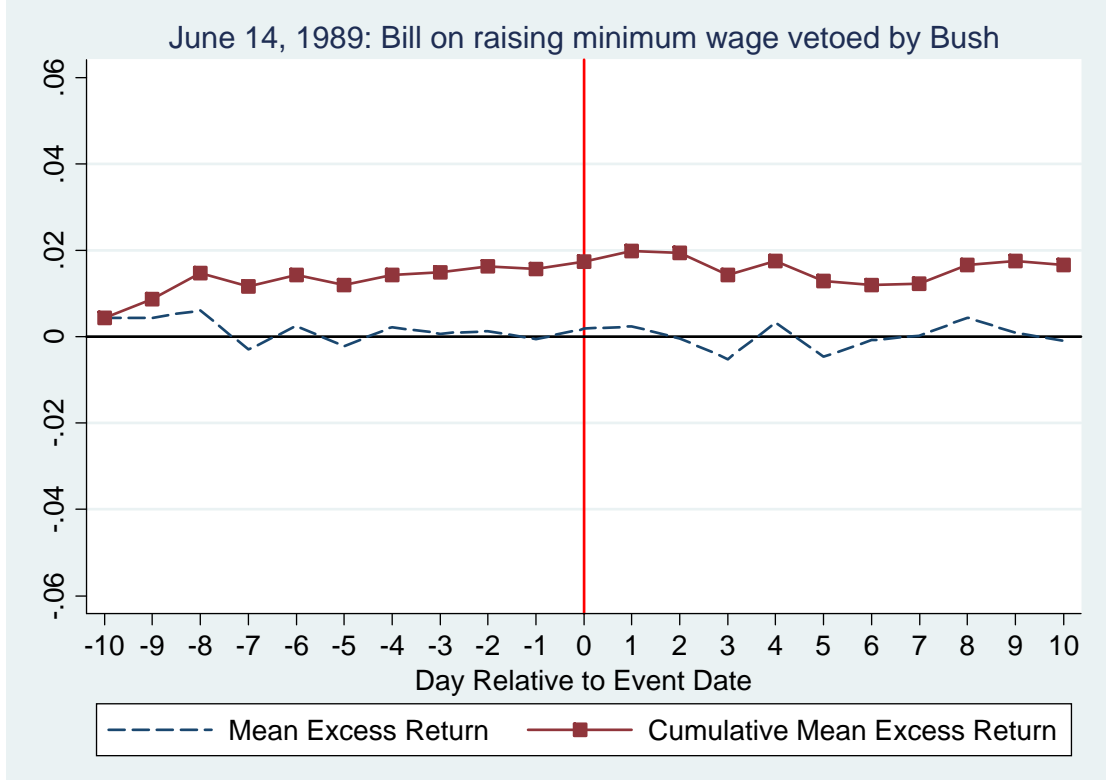

Table 5 June 14, 1989: Bill on raising minimum wage vetoed by Bush

\begin{tabular}{lcc}
\hline \multicolumn{1}{c}{ Prediction: Positive Effect } & Day 1-10 (\%) & Share \\
\hline Mean Excess Return & $\begin{array}{c}.0091909 \\
(.08159)\end{array}$ & $100 \%$ \\
Explained by the Market & $\begin{array}{c}.007856^{* * *} \\
(.0022258)\end{array}$ & $85.476 \%$ \\
Not Explained by the Market & $\begin{array}{c}.0013348 \\
(.081618)\end{array}$ & $14.524 \%$ \\
\hline Mean Excess Return & $\begin{array}{l}.0091909 \\
(.08159)\end{array}$ & $100 \%$
\end{tabular}




\begin{tabular}{ccc} 
Due to Differences in Market Performances & $\begin{array}{c}.007856^{* * *} \\
(.0022258)\end{array}$ & $85.476 \%$ \\
Due to Differences in Systematic Risks $\beta$ & $-3.6858 \mathrm{e}-04$ & $-4.010 \%$ \\
& $\begin{array}{c}(9.0407 \mathrm{e}-04) \\
\text { Due to Differences in Firm-specific Traits } \alpha\end{array}$ & $\begin{array}{c}.0017034 \\
(.081647)\end{array}$ \\
\hline \hline
\end{tabular}

\subsubsection{November 1, 1989 - Headline: Compromise Bill on Minimum Wage Reached and the House Passed H.R. 2710 by a Margin of 382 to 37}

The U.S. Congress took up the minimum wage again in the fall of 1989. On November 1, 1989, the Wall Street Journal reported that President Bush and Congressional Democrats had reached a compromise agreement on the minimum wage, clearing the way for eventual passage of the legislation. On November 1, 1989, the House passed H.R. 2710 by a margin of 382 to 37 . This bill increased the minimum wage to $\$ 3.80$ per hour on April 1, 1990, and to $\$ 4.25$ per hour on April 1, 1991, and created a 60-day youth subminimum wage. One week later, the Senate passed identical legislation by a vote of 89 to 8 .

Figure 7 depicts the mean excess return and cumulative mean excess return of this event. From the figure it is difficult to see whether the news has a negative effect on employer wealth. Table 6 shows that the post-event mean excess return is $-0.011 \%$ but not significant. By decomposing the negative excess return, we find that only $15.5 \%$ is explained by the market and largely $84.5 \%$ is not explained by the market though it is not significant from zero. By examining further, we found that $46 \%$ can be significantly attributed to differences in systematic risks $\beta$ at $5 \%$ level; 38\% can be attributed to differences in firm-specific traits but not statistically significant.

In sum, the Card and Krueger (1995) found a negative but not significant effect of this minimum-wage legislation on employer wealth. In spite of the insignificant outcome, we further examine the sources of the effect and show that market performance plays a relatively small role (15\%). Most of the negative effect (85\%) is not explained by the market. Differences in systematic risks and firm-specific traits contribute $46 \%$ and $38 \%$ to the negative excess return, respectively. Hence, our findings show that the compromise of the minimum wage bill and the passage in the House has an adverse effect on the sample companies. Economy-wide factors play a small role. 
Figure 7 November 1, 1989: Compromise bill on minimum wage reached and the House passed H.R. 2710 by a margin of 382 to 37

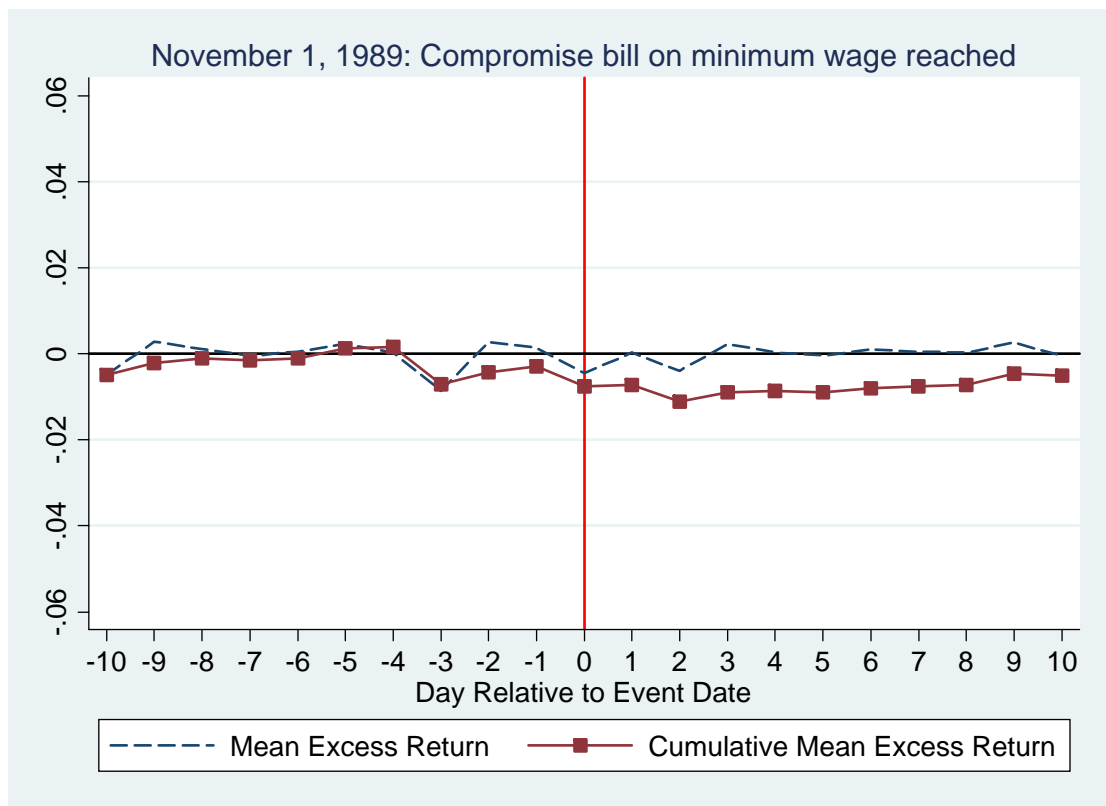

Table 6 Event: November 1, 1989: Compromise bill on minimum wage reached and the House passed H.R. 2710 by a margin of 382 to 37

\begin{tabular}{lcc}
\hline \multicolumn{1}{c}{ Prediction: Negative Effect } & Day 1-10 (\%) & Share \\
\hline Mean Excess Return & $\begin{array}{c}-.01091 \\
(.075326)\end{array}$ & $100 \%$ \\
\hline Explained by the Market & $\begin{array}{c}-.0016898^{* * *} \\
(3.7288 \mathrm{e}-04)\end{array}$ & $15.49 \%$ \\
Not Explained by the Market & $\begin{array}{c}-.0092201 \\
(.075327)\end{array}$ & $84.51 \%$ \\
\hline Mean Excess Return & $\begin{array}{c}-.01091 \\
(.075178)\end{array}$ & $100 \%$ \\
\hline Due to Differences in Market Performances & $\begin{array}{c}-.0016898 * * \\
(3.7288 \mathrm{e}-04)\end{array}$ & $15.49 \%$ \\
Due to Differences in Systematic Risks $\beta$ & $\begin{array}{c}-.0050552^{* *} \\
(.002073)\end{array}$ & $46.34 \%$ \\
Due to Differences in Firm-specific Traits $\alpha$ & $\begin{array}{l}-.0041648 \\
(.075345)\end{array}$ & $38.17 \%$ \\
\hline \hline
\end{tabular}

\section{Conclusion}

Minimum wages exist in more than one hundred countries, both industrialized and developing. The goals associated with the minimum wage are widely accepted as right 
and proper. However, there is much less agreement about whether the minimum wage is effective at attaining these goals. Although overwhelmingly popular with the public in the United States, the minimum wage has, from the time of its introduction, been highly controversial in the political arena. In addition, minimum wages have typically received less support from economists, who from the very beginning of the minimum wage debate pointed to the potential loss of jobs stemming from a wage floor. Despite decades of economic research, policy debates about the costs and benefits of minimum wages continue to the present day.

Based on their comprehensive reading of the evidence, Neumark and Wascher (2008) argue that minimum wages do not achieve the main goals set forth by their supporters. They reduce employment opportunities for less-skilled workers and tend to reduce their earnings; they appear to have adverse longer-term effects on wages and earnings, in part by reducing the acquisition of human capital. In comparison with the vast literature on the effects of the minimum wage on employment and wages, research on the influence of minimum wages on firm profits has been relatively little.

Among the few studies, Card and Krueger (1995) examine the economic impact of 1989 minimum wage hike on the welfare of 110 firms which employ a disproportionate number of minimum-wage workers. Their results show mixed evidence that excess returns associated with news about the 1989 minimum-wage legislation are generally unsystematic and rarely seems to have effect on shareholder wealth. We present a simple and intuitive approach to re-examine their results by decomposing excess returns.

Our results confirm Card and Krueger (1995) by decomposing mean excess returns. Table 7 summarizes our key findings. We found that the apparent lack of an effect is a consequence of two off-setting forces: (1) a negative effect arising from firmspecific traits (adverse information on minimum-wage worker employers) and (2) a positive effect arising from market performance. Our more nuanced view shows that while the aggregate effect of the 1989 minimum wage hike was neutral, there was a significant negative impact on firms that was neutralized by positive market performance. 
Table 7 Summary of Key Results

Cumulative Excess Return

in

Decomposition of Mean Excess Return (\%)

Event

Card and Krueger (1995)

$\mathrm{T}=-10$ to $10 \quad \mathrm{~T}=1$ to 10

June 12, 1987

1 Reagan may ease minimum wage $.027^{*}$ stand.

$0152 *$

Mean Excess Return

$\mathrm{T}=1$ to 10

Share

$24738 * * * \quad 100 \%$

Explained by the Market

.08678* $\quad 35.08 \%$

Not Explained by the Market

\section{Mean Excess Return}

Due to Differences in Market Performances

Due to Differences in Systematic Risks

Due to Differences in Firm-specific Traits

\section{Mean Excess Return}

Explained by the Market

March 4, 1988

2 Panel votes bill to sharply boost

Not Explained by the Marke

minimum wage.

$$
-.0276 * * *
$$

\section{Mean Excess Return}

Due to Differences in Market Performances

Due to Differences in Systematic Risks

Due to Differences in Firm-specific Traits

Mean Excess Return

September 27, 1988

3 Democrats' bid to boost minimum

wage this year is thwarted by GOP

$.039 * *$

$.0320 * * *$

filibuster.

March 3, 1989

Bush to propose raising minimum

wage to $\$ 4.25$ an hour, a lower

.017

training pay.

Explained by the Market

Not Explained by the Marke

Due to Differences in Market Performances

Due to Differences in Systematic Risks

Due to Differences in Firm-specific Traits

Mean Excess Return

Explained by the Marke

Not Explained by the Market

\section{Mean Excess Return}

Due to Differences in Market Performances

Due to Differences in Systematic Risks

$.24738 * * * \quad 100 \%$

$64.92 \%$

$.086779 * \quad 35.08 \%$

7.3119e-06 $\quad .003 \%$

$077749 \quad 100 \%$

44996*** $578.72 \%$

$-.37221^{* * *} \quad-478.72 \%$

$077749 \quad 100 \%$

$.44996 * * * \quad 578.72 \%$

9.2706e-04 $1.20 \%$

\begin{tabular}{ll}
$-.37313^{* * *}$ & $-479.92 \%$ \\
\hline $42005 * * *$ & $100 \%$
\end{tabular}

$.07721 * * * \quad 18.38 \%$

$.34283 * * * \quad 81.62 \%$

$.42005^{* * *} \quad 100 \%$

$.07721 * * * \quad 18.38 \%$

$-4.2676 \mathrm{e}-04 \quad-.10 \%$

$.34326 * * * \quad 81.72 \%$

12594

$100 \%$

$.10732 * * * \quad 85.22 \%$

$12594 \quad 100 \%$

$.10732 * * * \quad 85.22 \%$

$9.8981 \mathrm{e}-04 * \quad 0.78 \%$ 
Due to Differences in Firm-specific Traits Mean Excess Return

Explained by the Market

June 14, 1989

5 Bill on raising minimum wage

.015

$-.0009$

vetoed by Bush.

Not Explained by the Market

Mean Excess Return

Due to Differences in Systematic Risks

Due to Differences in Firm-specific Traits

Mean Excess Return

Explained by the Market

November 1, 1989

6 Compromise bill on minimum

.002

.0024

Not Explained by the Market wage reached.

\begin{tabular}{ccc} 
Not Explained by the Market & $-.00169^{* * *}$ & $15.49 \%$ \\
\hline Mean Excess Return & -.01091 & $84.51 \%$ \\
Due to Differences in Market Performances & $-.00169^{* * *}$ & $100 \%$ \\
Due to Differences in Systematic Risks & $-.00506^{* *}$ & $46.49 \%$ \\
Due to Differences in Firm-specific Traits & -.00416 & $38.17 \%$
\end{tabular}

Note: The sample size ranges between 102 and 108. * Significant at the 10\% level. ** Significant at the 5\% level. *** Significant at the $1 \%$ level. 


\section{References}

Althauser, Robert P. and Michael Wigler. 1972. "Standardization and Component Analysis." Sociological Methods Research, 1(1), 97-135.

Beaver, William; Paul Kettler and Myron Scholes. 1970. "The Association between Market-Determined and Accounting-Determined Risk Measures." The Accounting Review, 10(2), 654-82.

Becker, Brian E. and Craig A. Olson. 1986. "The Impact of Strikes on Shareholder Equity." Industrial and Labor Relations Review, 39(3), 425-38.

Black, Fischer; Michael C. Jensen and Myron Scholes. 1972. The Capital Asset Pricing Model: Some Empirical Tests. New York, NY: Praeger Publishers Inc.

Blinder, Alan S. 1973. "Wage Discrimination: Reduced Form and Structural Estimates." The Journal of Human Resources, 8(4), 436-55.

Boehmer, Ekkehart; Jim Musumeci and Annette B. Poulsen. 1991. "Event-Study Methodology under Conditions of Event-Induced Variance." Journal of Financial Economics, 30(2), 253-72.

Brown, Philip and Ray Ball. 1967. "Some Preliminary Findings on the Association between the Earnings of a Firm, Its Industry, and the Economy." Journal of Accounting Research, 5, 55-77.

Brown, Stephen J. and Jerold B. Warner. 1980. "Measuring Security Price Performance." Journal of Financial Economics, 8(3), 205-58.

Brown, Stephen J. and Jerold B. Warner. 1985. "Using Daily Stock Returns." Journal of Financial Economics, 14(1), 3-31.

Campbell, John Y.; Andrew W. Lo and A. Craig MacKinlay. 1997. The Econometrics of Financial Markets. Princeton, New Jersey: Princeton University Press.

Card, David and Alan B. Krueger. 1995. Myth and Measurement: The New Economics of the Minimum Wage. Princeton: Princeton University Press.

Chen, Son-Nan and Arthur J. Keown. 1981. "Risk Decomposition and Portfolio Diversification When Beta Is Nonstationary: A Note." The Journal of Finance, 36(4), 941-47.

Coleman, James S. ; Charles C. Berry and Zahava D. Blum. 1970. "White and Black Careers During the First Ten Years of Work Experience: A Simultaneous Consideration of Occupational Status and Income Changes," Johns Hopkins University Center for Social Organization of Schools Report 76,

Coleman, James S. and Zahava D. Blum. 1971. "Note on the Decomposition of 
Differences between Two Groups," Johns Hopkins University,

Corrado, Charles J. 2009. "Event Studies: A Methodology Review," Available at SSRN: http://ssrn.com/abstract=1441581,

Cotton, Jeremiah. 1988. "On the Decomposition of Wage Differentials." Review of Economics \& Statistics, 70(2), 236-43.

Cowan, Arnold. 2003. Eventus 8.0 User's Guide. Ames, Iowa: Cowan Research LC.

Draca, M.; S. Machin and J. Van Reenen. 2011. "Minimum Wages and Firm Profitability." American Economic Journal-Applied Economics, 3(1), 129-51.

Duncan, Otis Dudley 1969. "Inheritance of Poverty or Inheritance of Race?," D. P. Moynihan, On Understanding Poverty. New York: Basic Books, 85-110.

Duncan, Otis Dudley; David L. Featherman and Beverly Duncan. 1968. Socioeconomic Background and Occupational Achievement: Extensions of a Basic Model. New York and London: Seminar Press.

Elton, Edwin J. and Martin J. Gruber. 1995. Modern Portfolio Theory and Investment Analysis. John Wiley \& Sons, Inc.

Fama, Eugene F. 1976. Foundations of Finance: Portfolio Decisions and Securities Prices Basic Books.

Fama, Eugene F.; Lawrence Fisher; Michael C. Jensen and Richard Roll. 1969. "The Adjustment of Stock Prices to New Information." International Economic Review, 10(1), 1-21.

Fisher, Lawrence and James H. Lorie. 1968. "Rates of Return on Investments in Common Stock: The Year-by-Year Record, 1926-65." The Journal of Business, 41(3), 291-316.

Fisher, L. and J. H. Lorie. 1964. "Rates of Return on Investments in Common Stocks." The Journal of Business, 37(1), 1-21.

Gardeazabal, Javier and Arantza Ugidos. 2004. "More on Identification in Detailed Wage Decompositions." The Review of Economics and Statistics, 86(4), 1034-36.

Horrace, William C. and Ronald L. Oaxaca. 2001. "Inter-Industry Wage Differentials and the Gender Wage Gap: An Identification Problem." Industrial and Labor Relations Review, 54(3), 611-18.

Jann, Ben. 2008. "A Stata Implementation of the Blinder-Oaxaca Decomposition," ETH Zurich Sociology Working Papers No.5,

Jones, F. L. 1983. "On Decomposing the Wage Gap: A Critical Comment on Blinder's 
Method." The Journal of Human Resources, 18(1), 126-30.

Jones, F. L. and Jonathan. Kelley. 1984. "Decomposing Differences between Groups. A Cautionary Note on Measuring Discrimination." Sociological Methods and Research, 12(3), 323-43.

Khotari, S. P. and Jerold B. Warner. 2007. "Econometrics of Event Studies," B. E. Eckbo, Handbook of Corporate Finance: Empirical Corporate Finance. Elsevier/North Holland,

King, Benjamin F. 1966. "Market and Industry Factors in Stock Price Behavior." The Journal of Business, 39(1), 139-90.

Lin, Carl. 2011. "Decomposing Excess Returns in Stochastic Linear Models," IZA Discussion Paper No. 6237.

Lin, Carl. 2011. "Give Me Your Wired and Your Highly Skilled: Measuring the Impact of Immigration Policy on Employers and Shareholders," IZA Discussion Paper No. 5754., IEB Working Paper Series [2011/17].

Lin, Eric S. 2007. "On the Standard Errors of Oaxaca-Type Decompositions for InterIndustry Gender Wage Differentials." Economics Bulletin, 10(6), 1-11.

Lintner, John. 1965. "The Valuation of Risk Assets and the Selection of Risky Investments in Stock Portfolios and Capital Budgets." The Review of Economics and Statistics, 47(1), 13-37.

Neumark, David and William L. Wascher. 2008. Minimum Wages. Cambridge, Mass.: MIT Press.

Oaxaca, Ronald L. 1973. "Male-Female Wage Differentials in Urban Labor Markets." International Economic Review, 14(3), 693-709.

Oaxaca, Ronald L. and Michael R. Ransom. 1998. "Calculation of Approximate Variances for Wage Decomposition Differentials." Journal of Economic and Social Measurement, 24(1), 55-61.

Oaxaca, Ronald L. and Michael R. Ransom. 1999. "Identification in Detailed Wage Decompositions." The Review of Economics and Statistics, 81(1), 154-57.

Oaxaca, Ronald L. and Michael R. Ransom. 1994. "On Discrimination and the Decomposition of Wage Differentials." Journal of Econometrics, 61(1), 5-21.

Patell, James M. 1976. "Corporate Forecasts of Earnings Per Share and Stock Price Behavior: Empirical Tests." Journal of Accounting Research, 14(2), 246-74.

Peterson, Parmela P. 1989. "Event Studies: A Review of Issues and Methodology." Quarterly Journal of Business and Economics, 28(3), 36-66. 
Piotroski, Joseph D. and Barren T. Roulstone. 2004. "The Influence of Analysts, Institutional Investors, and Insiders on the Incorporation of Market, Industry, and Firm-Specific Information into Stock Prices." The Accounting Review, 79(4), 1119-51.

Powers, Daniel A.; Hirotoshi Yoshioka and Myeong-Su Yun. 2011(forthcoming). "Mvdcmp: Multivariate Decomposition for Nonlinear Response Models." The Stata Journal.

Prager, Robin A. 1989. "Using Stock Price Data to Measure the Effects of Regulation: The Interstate Commerce Actand the Railroad Industry." The RAND Journal of Economics, 20(2), 280-90.

Ross, Stephen A. 1976. "The Arbitrage Theory of Capital Asset Pricing." Journal of Economic Theory, 13(1), 341-60.

Ruback, Richard S. and Martin B. Zimmerman. 1984. "Unionization and Profitability: Evidence from the Capital Market." Journal of Political Economy, 92(6), 1134-57.

Schwert, G. William. 1981. "Using Financial Data to Measure Effects of Regulation." Journal of Law and Economics, 24(1), 121-58.

Sharpe, William F. 1964. "Capital Asset Prices: A Theory of Market Equilibrium under Conditions of Risk." Journal of Finance, 19(1), 425-42.

Winsborough, H.H. and Peter Dickinson. 1971. "Components of Negro-White Income Differences." Proceedings of the Social Statistics Section of the American Statistical Association, Social Statistics Section, 6-8.

Yun, Myeong-Su. 2004. "Decomposition Differences in the First Moment." Economics Letters, 82(2), 275-80.

Yun, Myeong-Su. 2007. "An Extension of the Oaxaca Decomposition Using Generalized Residuals." Journal of Economic and Social Measurement, 32(1), 15-22.

Yun, Myeong-Su. 2005. "Hypothesis Tests When Decomposing Differences in the First Moment." Journal of Economic and Social Measurement, 30(4), 295-304.

Yun, Myeong-Su. 2005. "A Simple Solution to the Indentification Problem in Detailed Wage Decompositions." Economic Inquiry, 43(4), 766-72. 
Appendix

Table A 1110 Companies Used in the Analysis

\begin{tabular}{|c|c|c|c|}
\hline Company Name & Primary Industry & PERMNO* & SICCD** \\
\hline Albertson's Inc. & Grocery Stores & 50032 & 5411 \\
\hline AMC Entertainment Inc. & $\begin{array}{l}\text { Motion Picture } \\
\text { Theaters, Except } \\
\text { Drive-ins }\end{array}$ & 66413 & 7832 \\
\hline American Stores Co. & Grocery Stores & 44652 & 5912 \\
\hline Ampal American Israel Corp. & Hotels and Motels & 64864 & 6799 \\
\hline Angelica Corp. & Linen Supply & 45583 & 2337 \\
\hline Arden Group Inc. & Grocery Stores & 14868 & 5410 \\
\hline Ark Restaurants Corp. & Eating Places & 85586 & 5810 \\
\hline Bayport Restaurant Group Inc. & Eating Places & 21304 & $5812^{\mathrm{a}}$ \\
\hline Benihana National Corp. & Eating Places & 17671 & 5812 \\
\hline Brendle’s Inc. & Variety Stores & 10282 & 5990 \\
\hline Brinker International Inc. & Eating Places & 23297 & 5812 \\
\hline Bruno’s Inc. & Grocery Stores & 19589 & 5411 \\
\hline Buffets Inc. & Eating Places & 86167 & 5812 \\
\hline Carl Karcher Enterprises Inc. & Eating Places & 47133 & 5812 \\
\hline Carmike Cinemas Inc. & $\begin{array}{l}\text { Motion Picture } \\
\text { Theaters, Except } \\
\text { Drive-ins }\end{array}$ & 10750 & 7832 \\
\hline Carter Hawley Hale Stores Inc. & Department Stores & 40352 & $5311^{\mathrm{a}}$ \\
\hline Casey’s General Stores Inc. & Grocery Stores & 21742 & 5399 \\
\hline Cineplex Oden Corp. & $\begin{array}{l}\text { Motion Picture } \\
\text { Theaters, Except } \\
\text { Drive-ins }\end{array}$ & 75045 & 6711 \\
\hline Cintas Corp. & Linen Supply & 23660 & 7213 \\
\hline Chart House Enterprises Inc. & Eating Places & 75815 & $5812^{b}$ \\
\hline Club Med Inc. & Hotels and Motels & 66464 & 7011 \\
\hline Consolidated Products Inc. & Eating Places & 26607 & 5812 \\
\hline Consolidated Stores Corp. & Variety Stores & 67467 & 5531 \\
\hline Cracker Barrel Old Country Store Inc. & Eating Places & 27562 & 5812 \\
\hline Craig Corp. & Grocery Stores & 49496 & 5041 \\
\hline Crowley Milner \& Co. & Department Stores & 31026 & 5311 \\
\hline Dairy Mart Convenience Stores Inc. & Grocery Stores & 87151 & 5411 \\
\hline Dayton Hudson Corp. & Variety Stores & 49154 & 5311 \\
\hline Delchamps Inc. & Grocery Stores & 29226 & 5411 \\
\hline Dial Corp. DE & Eating Places & 19721 & 4131 \\
\hline Dillard Department Stores Inc. & Department Stores & 49429 & 5311 \\
\hline Dollar General Corp. & Variety Stores & 30382 & 5399 \\
\hline El Chico Restaurant Inc. & Eating Places & 31748 & 5812 \\
\hline Family Dollar Stores Inc. & Variety Stores & 53866 & 5331 \\
\hline Family Steak Houses of Florida Inc. & Eating Places & 10170 & 5810 \\
\hline Federated Department Stores Inc. & Department Stores & 18550 & $5311^{\mathrm{a}}$ \\
\hline
\end{tabular}




\begin{tabular}{|c|c|c|c|}
\hline Food Lion Inc. & Grocery Stores & 37189 & 5411 \\
\hline Foodarama Supermarkets Inc. & Grocery Stores & 47036 & 5411 \\
\hline Frisch’s Restaurants Inc. & Eating Places & 57330 & 5812 \\
\hline G \& K Services Inc. & Linen Supply & 37955 & 7213 \\
\hline Gander Mountain Inc. & $\begin{array}{l}\text { Miscellaneous } \\
\text { Merchandise Stores }\end{array}$ & 10141 & 5960 \\
\hline Giant Food Inc. & Grocery Stores & 32205 & 5411 \\
\hline Gottschalks Inc. & Department Stores & 69411 & 6711 \\
\hline Ground Round Restaurants Inc. & Eating Places & 49736 & 5810 \\
\hline Hannaford Bros Co. & Grocery Stores & 59301 & 5141 \\
\hline Healthcare Services Group Inc. & Linen Supply & 41292 & 8059 \\
\hline Hilton Hotels Corp. & Hotels and Motels & 23309 & 7011 \\
\hline Ingles Markets Inc. & Grocery Stores & 11701 & 5410 \\
\hline Jamesway Corp. & Department Stores & 48100 & 5311 \\
\hline JB’s Restaurants Inc. & Eating Places & 46114 & 5812 \\
\hline Kahler Corp. & Hotels and Motels & 46958 & 7011 \\
\hline Kmart Corp. & Department Stores & 89757 & 5331 \\
\hline Kroger Co. & Grocery Stores & 16678 & 5411 \\
\hline L. Luria \& Son Inc. & $\begin{array}{l}\text { Miscellaneous } \\
\text { Merchandise Stores }\end{array}$ & 62316 & 5961 \\
\hline La Quinta Inns Inc. & Hotels and Motels & 58624 & 7011 \\
\hline Luby’s Cafeterias Inc. & Eating Places & 64020 & 5812 \\
\hline Mac Frugal's Bargain Close Outs Inc. & Variety Stores & 62894 & 5331 \\
\hline Marcus Corp. & Hotels and Motels & 51423 & 7011 \\
\hline Max \& Erma’s Restaurants Inc. & Eating Places & 51984 & 5812 \\
\hline May Department Stores Co. & Department Stores & 13100 & 5311 \\
\hline McDonald's Corp. & Eating Places & 43449 & 5812 \\
\hline Mercantile Stores Co. Inc. & Department Stores & 22891 & 5311 \\
\hline Morgan’s Foods Inc. & Eating Places & 64442 & 2033 \\
\hline Morrison Restaurants Inc. & Eating Places & 55213 & 5812 \\
\hline Motts Holdings Inc. & Grocery Stores & 40731 & 5411 \\
\hline National Convenience Stores Inc. & Grocery Stores & 60978 & $5411^{\mathrm{a}}$ \\
\hline National Pizza Co. & Eating Places & 56630 & 5212 \\
\hline Neiman Marcus Group Inc. & Department Stores & 75179 & 5311 \\
\hline Orient Express Hotels Inc. & Hotels and Motels & 66085 & 7011 \\
\hline Pancho’s Mexican Buffet Inc. & Eating Places & 61058 & 5812 \\
\hline PEC Israel Economic Corp. & Grocery Stores & 66296 & 6052 \\
\hline Penn Traffic Co. & Grocery Stores & 75310 & 5411 \\
\hline Pepsico Inc. & Eating Places & 13856 & 2086 \\
\hline Piccadilly Cafeterias Inc. & Eating Places & 62907 & 5812 \\
\hline Proffitt's Inc. & Department Stores & 11382 & 5311 \\
\hline Quality Food Centers Inc. & Grocery Stores & 11215 & 5411 \\
\hline Rio Hotel \& Casino Inc. & Hotels and Motels & 12395 & 7011 \\
\hline Riser Foods Inc. & Grocery Stores & 75359 & 5141 \\
\hline Rose’s Stores Inc. & Variety Stores & 67620 & 5331 \\
\hline Ruddick Corp. & Grocery Stores & 54818 & 2281 \\
\hline
\end{tabular}




\begin{tabular}{llll|}
\hline Ryan's Family Steak Houses Inc. & Eating Places & 68049 & 5812 \\
\hline S K I Ltd. & Hotels and Motels & 91636 & 7999 \\
\hline Sbarro Inc. & Eating Places & 67715 & 5812 \\
\hline Schultz Sav O Stores Inc. & Grocery Stores & 12253 & 5410 \\
\hline Sears Roebuck \& Co. & Department Stores & 14322 & 5311 \\
\hline Seaway Food Town Inc. & Grocery Stores & 69682 & 5411 \\
\hline Service Merchandise Co Inc. & Miscellaneous & 70077 & 5961 \\
\hline Shoney's Inc. & Merchandise Stores & 70376 & 5812 \\
\hline Sizzler International Inc. & Eating Places & 56354 & 5812 \\
\hline Smith's Food \& Drug Center Inc. & Eating Places & 75602 & 5411 \\
\hline Spaghetti Warehouse Inc. & Grocery Stores & 90676 & 5812 \\
\hline Stop \& Shop Cos. Inc. & Eating Places & 36986 & 5411 \\
\hline Strawbridge \& Clothier & Grocery Stores & 73083 & 5311 \\
\hline Stuarts Department Stores Inc. & Department Stores & 73171 & 5311 \\
\hline Thousand Trails Inc. & Variety Stores & 76102 & 7033 \\
\hline TPI Enterprises Inc. & Hotels and Motels & 75089 & 5810 \\
\hline Tuesday Morning Corp. & Eating Places & 10094 & 5710 \\
\hline Unifirst Corp. & Variety Stores & 65306 & 7213 \\
\hline United Inns Inc. & Linen Supply & 54420 & 7011 \\
\hline Unitog Co. & Hotels and Motels & 79410 & 2328 \\
\hline Uno Restaurant Corp. & Linen Supply & 75103 & 5812 \\
\hline Vicorp Restaurants Inc. & Eating Places & 80654 & 5812 \\
\hline Vie de France Corp. & Eating Places & 80785 & 5462 \\
\hline Volunteer Capital Corp. & Eating Places & 66747 & 5812 \\
\hline Vons Cos. Inc. & Eating Places & 22074 & 5411 \\
\hline Wal Mart Stores Inc. & Grocery Stores & 55976 & 5311 \\
\hline Wall Street Deli Inc. & Department Stores & 68743 & 5810 \\
\hline Walt Disney Co. & Eating Places & 26403 & 7813 \\
\hline Warehouse Club Inc. & Amusement Parks & 92997 & 5990 \\
\hline Weis Markets Inc. & Miscellaneous & 42059 & 5411 \\
\hline Wendy's International Inc. & Merchandise Stores & 63060 & 5812 \\
\hline Winn Dixie Stores Inc. & Grocery Stores & 24803 & 5411 \\
\hline Woolworth Corp. & Eating Places & 15456 & 5331 \\
\hline WSMP Inc. & Grocery Stores & 82449 & 5812 \\
\hline Nar PEs & Variety Stores & Eating Places & \\
\hline
\end{tabular}

Note: PERMNO is a unique permanent security identification number assigned by CRSP to each security. SICCD is the Standard Industrial Classification Code.

Source: Card and Krueger (1995) Table A.10.1. 